Article

\title{
An Integrated Approach to Explore the Relationship Among Economic, Construction Land Use, and Ecology Subsystems in Zhejiang Province, China
}

\author{
Chuyu Xia ${ }^{1}$, Yan $\mathrm{Li}^{1, *}$, Yanmei Ye ${ }^{1}$ and Zhou Shi ${ }^{2}$ \\ 1 Institute of Land Science and Property Management, School of Public Affairs, Zhejiang University, \\ Hangzhou 310058, China; xiachuyu1992@126.com (C.X.); yeyanmei@zju.edu.cn (Y.Y.) \\ 2 Institute of Agricultural Remote Sensing and Information Technology Application, \\ College of Environmental and Resource Sciences, Zhejiang University, Hangzhou 310058, China; \\ shizhou@zju.edu.cn \\ * Correspondence: liyan522@zju.edu.cn; Tel.: +86-571-5666-2139.
}

Academic Editor: Marc A. Rosen

Received: 21 March 2016; Accepted: 16 May 2016; Published: 21 May 2016

\begin{abstract}
Zhejiang Province, China is experiencing rapid urbanization, facing the challenge of coupling socioeconomic development and ecological conservation. This paper establishes a comprehensive index system to assess coordinating development of economic, construction land use (CLU), and ecology subsystems. A Granger test and a coupling coordination model were applied to explore the causal relationship and the coordinated development state among the three subsystems from 2000 to 2012. The results showed that: (1) changes in the integrated value of the economic subsystem were the Granger cause of changes in the ecology and CLU subsystems, and the changes in the integrated values of ecology and CLU was each other's Granger cause; (2) the coupling coordination relationship of the integrated value for economic-CLU-ecology was constrained by the relationship between the economic and the CLU subsystems from 2000 to 2004, and that between the ecology and the economic subsystems was the impediment of the sustainable development of economic-CLU-ecology from 2004 to 2012. This research helps to identify approach to sustainable development through analyzing synergistic effects, interdependencies, and trade-offs among the integrated economic-CLU-ecology values, and to make significant contribution to urban planning policies in rapid urbanization region.
\end{abstract}

Keywords: sustainable development; integrated value of economic; CLU; ecology; Granger test; coupling coordination degree model

\section{Introduction}

China has experienced fast-paced economic growth and a period of rapid urbanization following the country's reform and opening up in the late 1970s [1]. Kuznets defines economic development as the movement of a population from rural to urban areas. This movement requires an increase in city sizes, the expansion of the industrial and the service sectors [2], the creation of new infrastructure [3], and the building of more residential housing. All of these changes mean an increasing need for land that is defined for construction use. China experienced a dramatic increase (of 55.2 thousand $\mathrm{km}^{2}$ ) in the land that is defined for construction between 1990 and 2010 [4].

Construction land in this study refers to land that can be built on, including cities and towns, rural residential areas, independent industrial and mining land, and traffic land. The increase in the construction land has caused a sharp decrease in the amount of cultivated land, and threatened land productivity from ecological impact and the impact of cultivated land change induced by landscape 
variation, raising great concerns about China's ability of maintaining food self-sufficiency [5,6]. As to China's more developed eastern region, the urbanization has led to the loss of cultivated land increased by $29.2 \%$ from 2000 to 2008 compared with that from 1995-2000 [7]. Moreover, the rapid expansion of construction land and China's economic growth has irreversibly deteriorated the ecological and environmental quality of the land, posed a serious threat to environmental sustainability [8-10]. At present, China's urbanization and industrialization trends show no signs of abating. One could extrapolate that China's construction land demand will rise constantly in line with its past trends, even although the gross domestic product (GDP) is expected to decrease to $7 \%$ in the coming years. However, compared with Japan during its rapid economic development period, every 1\% GDP increase in China equates to eight times the land size of a similar increase in Japan [11]. China's extensive construction land use (CLU) is a crucial element affecting its long-term outlook for sustainable economic development, and for its ecological and environmental quality.

Thus, there is a great necessity to explore way of improving current extensive urban expansion and economic growth to a sustainable development mode through coupling relationship of economic, construction land use, and ecology. The speed of urbanization and industrialization in some regions in China has been so unprecedented and unique that it cannot be repeated in human development history [12]. Hence, it is critical to explore a scientific and effective decision way to achieve the goal of building resource-saving and environmentally friendly society.

As a representative of the eastern-coast developed provinces of China, Zhejiang Province has still faced a rigid demand for construction land resource. Unlike Beijing, Tianjin, Shanghai, and Chongqing, cities that are directly administered by the central government, cities of Zhejiang Province have been under the control of the provincial government. Local governments have encouraged land transfer to boost local revenue and attract more investment. Thus, in Zhejiang Province from 1999-2012, the average proportion of the land-transferring fee to fiscal revenue was $48.98 \%$, with the highest level being 79.96\% in 2003 (Figure 1). The substantial extra-budgetary revenue that is available through converting land use further stimulates the fiscal motives of local governments: they convert large amounts of rural use land into urban use land. This causes a phenomenon whereby the acquired lands are in disuse because of a market surplus; this, in turn, makes it possible for the developers to obtain further land use rights for low land-transferring fees. However, with rapid urbanization and industrialization, Zhejiang Province has been facing many ecological challenges such as extreme heat events, degraded visibility, air and water pollution. For example, the average visibility degraded dramatically by $1.8 \mathrm{~km} / 10$ a during the last three decades [13]. Therefore, Zhejiang Province should take measures to coordinate the relationship among economic, construction land use and ecology subsystem rather than passively wait for the arrival of the Kuznets curve inflection point between them.

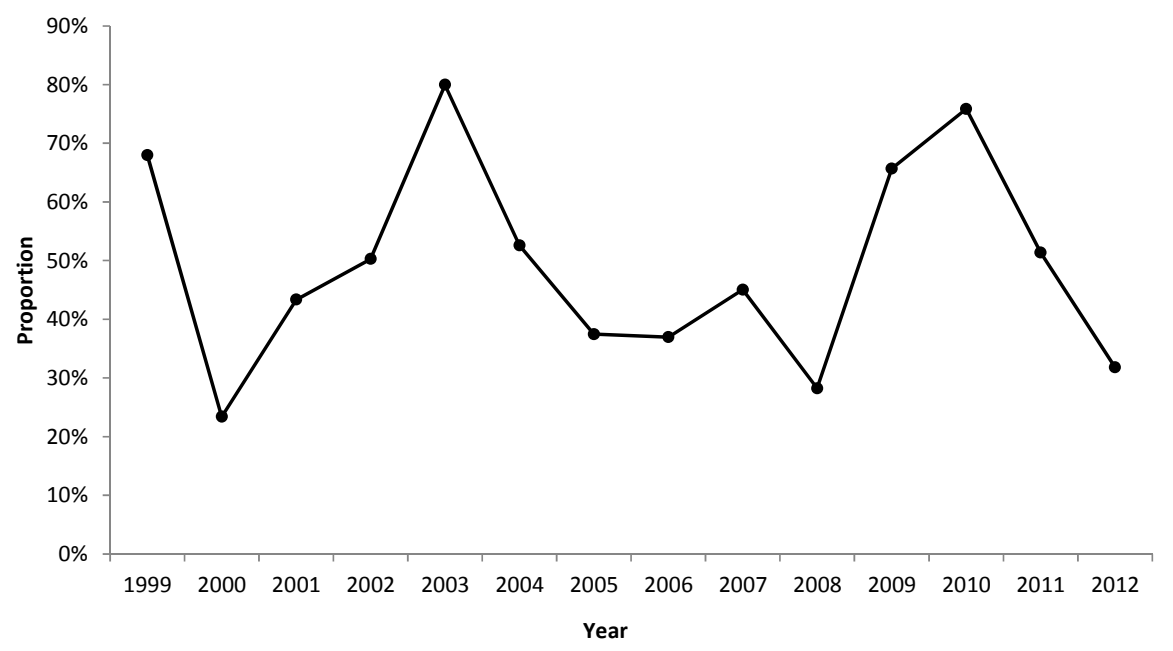

Figure 1. Zhejiang Province: Proportion of land-transferring fee to fiscal revenue, 1999-2012. 


\subsection{Current Construction Land Use (CLU) in China}

\subsubsection{Economic Factors}

Land that is newly converted to construction land is mainly transferred from agricultural land. The low cost of converting the land from an agricultural use to a construction use is the fundamental reason for the extensive use of such land. From a monetary perspective, in comparison with industrialization, the advantage of agricultural production is relatively low, and the income gap between agricultural land use and non-agricultural land use is continually increasing. Driven by the market mechanism, the high-value land-use pattern will squeeze the low-value land-use pattern. If there is no effective government intervention, then a lot of agricultural lands may be converted into construction land, which is not conducive to intensive land use.

The extensive use of rural construction land that contains rural residential land and other land of nonagricultural facilities in China reflects this point to a certain extent. To develop an urban region, the local government first acquires the agricultural land from the local farmers for a land acquisition fee. The local government then transfers the land-use rights to the developers, who pay a land-transferring fee to the local government. The existing compensation standards mean that the land acquisition fee is far lower than the land-transferring fee, which accounts for a large portion of China's fiscal revenue. At a national level, China's land-transferring fees in 2011 accounted for $60 \%$ of its total budgetary revenue, twice the level of 2001 [14].

The land' value increments are increasing in conjunction with China's rapid economic development. With the aim of maximizing their profits arising from the land' value increments, many developers (who obtained the land use rights at very low land-transferring fees) stockpile the lands, or temporarily stall their development. Developers delay developing lands until the land prices or the housing prices have increased greatly, resulting, in the interim, in much idle land. Currently, China's estimated idle land volume is $667 \mathrm{~km}^{2}$ (Ministry of Land and Resources of China, 2014).

\subsubsection{Institutional and Managerial Factors}

The intensive construction land is influenced by numbers of factors of legal framework and land use regulation as well. First, some of the construction land (including some old towns, old villages, and old factory buildings) has fallen into disuse, is abandoned, or has a relatively inefficient use, because the functions and the characteristics of its buildings are not suitable for modern lifestyles and production processes. Second, the restrictions on the transfer of land use rights, and the ambiguous property rights, limit the opportunity to change the use of land and to improve the use intensity [15]. Finally, the absence of rules and regulations related to extensive construction land indicates that local governments cannot help to address the problem.

\subsubsection{Extensive Construction Land}

Currently, China's extensive construction land mainly falls into three categories: urban, rural and industrial construction land.

Urban construction land: Unlike the suburbanization process in the west, urban expansion usually happens in urban fringe in order to share the existing infrastructure, such as public transport. Therefore, homocentric outspread within short-distance (normally within $10 \mathrm{~km}$ of the city center) is the most obvious characteristics in China's urban expansion. Without scientific and effective planning concept initially, many of urban expansions are directed by the projects, characterized by low-density spread [16]. However, many projects are spatially scattered so that it is difficult to form industry chains and enjoy the benefits of agglomeration [17]. Moreover, most projects are single purpose oriented, so that many suburban areas lack the infrastructure facilities, such as supermarkets and hospitals [18].

Rural construction land: Under the dual-track policy of rural-urban development in China, millions of migrations from the rural to the urban areas are not entitled to the same social welfares as the city dwellers [19]. This kind of insecurity drives them to constantly expand their rural residential 
land as pension assets. Moreover, despite millions of rural to urban migrant workers, rural homestead servitude cannot be transferred autonomously, resulting in large numbers of vacant rural houses. Additionally, undefined property rights of rural residential land, feudal systems and superstition, and nostalgia increase the difficulty of rural residential consolidation $[20,21]$. As a result, while rural population is decreasing, the area of construction land in rural areas has been increasing. In this way, more and more "village hollowing" has appeared. There has been a dramatic increase of the volume of rural housing land per capita by $18.28 \%$ from 1996 to 2007: it was $228 \mathrm{~m}^{2}$ per head in 2007, significantly higher than the national standard of $150 \mathrm{~m}^{2}$ per head.

Industrial land: To boost China's industrialization progress, industrial parks have mushroomed since the 1990s. China's accession to WTO in 2001 impelled China to be "world factory", resulting in appearance of numerous of industrial parks. At the outset of the industrial park process, local governments transferred the industrial land use rights at very low price to attract foreign investment. This strategy led to a great quantity of industrial land and hence rapid urban sprawl, at a tragic cost of a large number cultivated land and ecological land occupied [22,23].

China's 2003 national industrial park inventory accounted for 5658 industrial parks, with a planning districts of $36,000 \mathrm{~km}^{2}$, which exceeded China's total area of urban construction land in 2003 [24]. Furthermore, 55\% of the industrial parks are on what was formerly cultivated land. The current industrial-agricultural land imbalance and extensive industrial land use are unresolved problems [25]. First, the actual use area within the industrial parks is limited, meaning that the land is not fully used, and the land-use efficiency is low. Even in some national-level industrial parks, the development mode is still extensive (rather than intensive), and depends on the massive consumption of land, water and energy. Second, because of the insufficient capacity to attract foreign investment, the amount of idle land is huge, especially within some provincial-level industrial parks. Third, the land use structure within many industrial parks is irrational, with a very low proportion of industrial land, and a large proportion of non-productive land such as green land, residential land, commercial land, and other infrastructure land (e.g., schools). Finally, the low industrial land prices have prevented the desirous and significant change of urban expansion model from extensive use to intensive use [23].

Taking Zhejiang Province as an example, during the period 1999-2012 the industrial land with a mean value of $255 \mathrm{yuan} / \mathrm{m}^{2}$ (136 yuan $/ \mathrm{m}^{2}$ and $335 \mathrm{yuan} / \mathrm{m}^{2}$ for the lowest and highest prices, respectively) was transferred by bid and agreement. This value was lower than the average sale prices of residential land (1573 yuan $\left./ \mathrm{m}^{2}\right)$ and commercial land $\left(1834 \mathrm{yuan} / \mathrm{m}^{2}\right)$ during the same period (Figure 2).



Figure 2. Zhejiang Province land-transferring fees: commercial, residential and industrial land, 2000-2012. 


\subsection{Relationship among Economic Development, Construction Land Use (CLU) and Ecological Quality}

Economic development is the process of social material wealth accumulation and social reproduction, during which many factors (including land, capital, labor, and technology) interact. To realize a rapid and sustainable development within limited land resources, the land should be used intensively to improve its supporting capacity for economic development. Generally, the aim of intensive CLU is to improve the use efficiency and output. Economic development has a significant effect on the intensity level of CLU. Economic development can: promote the evolution of the industrial structure; result in changing land use structures and patterns; and improve the allocation and the use efficiency of the land resources. Intensive CLU can increase the total supply of the land resources; exploit the scale effect and the clustering effect; enable economies of capital, technology and labor; promote science and technology innovation; and transform the mode of economic development and optimize the industrial land layout to further improve the quality of the economic development [26].

The intensity level of CLU reflects the substitution relationship between the land and capital: the higher the relative price of land, the greater the capital investment per unit land, and the higher the intensity degree of land use [27]. According to the substitution principle, the essential productive factors can be substituted for each other to some extent. As shown in Figure 3, the investors can control cost through combining the productive factors. Many empirical estimates indicate that the capital-land substitution elasticity is between 0.36 and 1.2 [28].

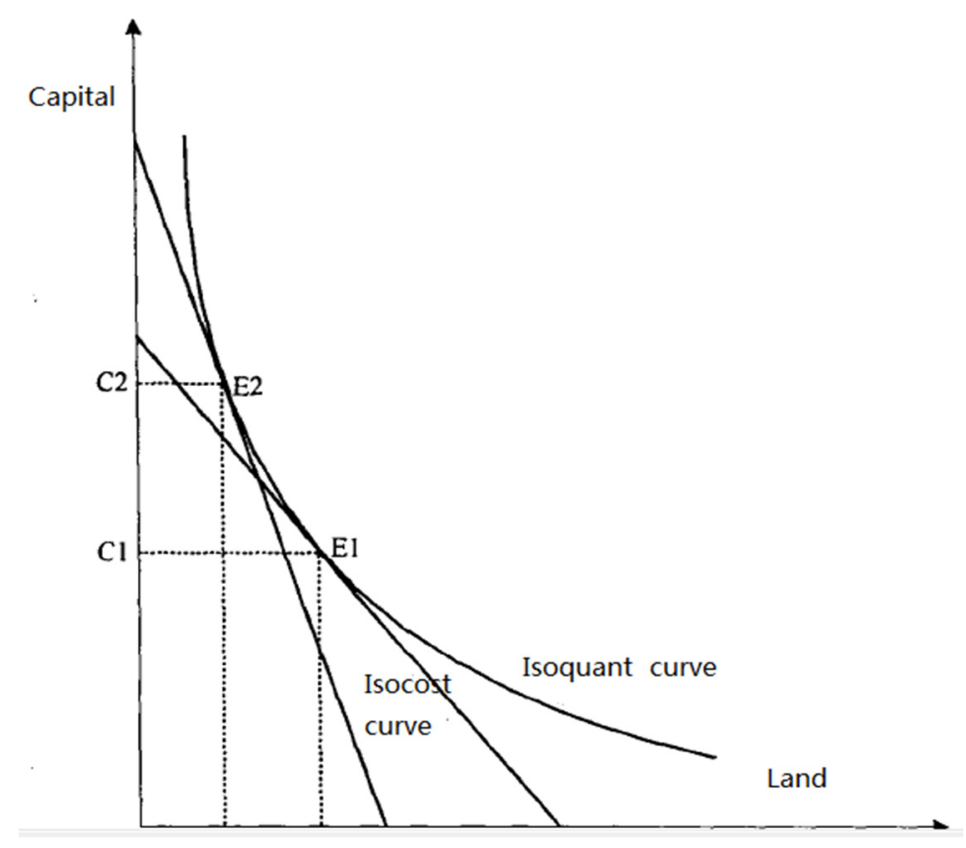

Figure 3. Substitution relationship between capital and land.

The relationship between the integrated value of CLU and of economic development is a dynamic process. In its different stages, economic development has different patterns, and places different demands on the land resources, which result in different CLU intensity levels. Generally, the early stages of economic development are characterized by a shortage of capital: investors tend to use more land (rather than capital) in their investments, and the land is usually used extensively. As the economic development level improves, capital is continuously accumulated, and the scarcity of the land resource becomes increasingly prominent. With the relative price increase of land, the investors tend to use more capital in their investments, the land is used intensively to obtain a higher output [27].

During urbanization, the dynamic change process between the socio-economic and the ecological capacity fundamentally accords with a logistic curve, called the Kuznets curve [29,30] (Figure 4). 
This means that the socio-economic capacity stresses a coercing effect on the ecological capacity, and the effect of the latter on the former is hysteretic [31], which is specified as a double-exponential curve [32-34].
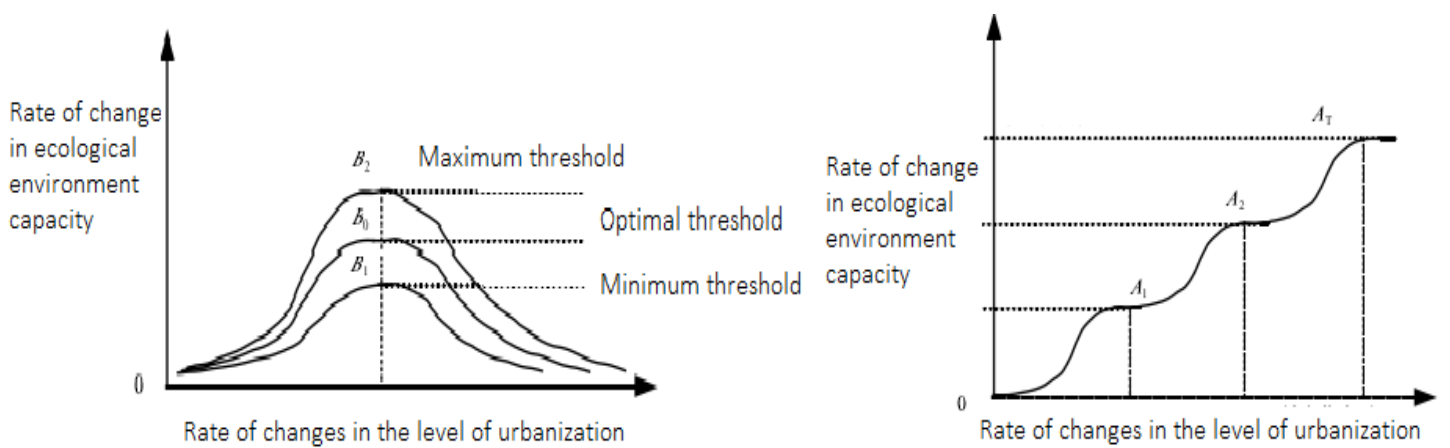

Figure 4. Urbanization and ecological environment: Inverse U-shaped curve and logistics process curve.

The coercing effect of socio-economic development on the ecological quality is analyzed from the perspectives of population agglomeration, economic growth, and construction land expansion. Moreover, the resource status, the ecological condition, and environmental pollution all limit socio-economic development [35]. For example, although the human migration from the rural areas to the cities increases the discharge of urban domestic waster and the consumption of residential land, it also alleviates the pressure on the rural environment, especially in the ecological vulnerable region [36].

The economic growth has caused the environmental pollution and ecological degradation, but it also has increased the resource use efficiency and the investment in ecological environment. This indicates the economic growth and technological advances have a mutual promotion effect, which in turn are beneficial to update and optimize the industrial structure. The resource allocation and the economic structure would be optimized by the interactive coercing effect between the integrated values of the socio-economic and the ecological change rates. Finally, the evolution of the integrated value of socio-economic and ecology would be promoted to a high-level harmonious coupling relationship.

\subsection{Literature Review}

The current studies on the relationship among the integrated values of economic development, CLU and ecological quality can be roughly classified into two categories. The first category argues that land is an indispensable production factor, and that economic development is one of the driving forces of construction land expansion. The case studies that follow this rationale examine how the expansion of construction land promotes economic development at the national, provincial, and county levels.

Chen (2010) concludes that GDP is the biggest driving force for the expansion of construction land by analyzing the different driving forces in China's regions (east, middle, and west) and at the national level [37]. Shu (2013) reveal that economic development, population growth, and industrial structure adjustment are the main driving forces of urban sprawl, and that urban construction land plays an important role in economic development and in the urbanization process [38]. Ye et al. (2012) find that a regional socio-economic development would not only drive the expansion of construction land itself, but would also lead to the construction land growth of the ambient areas [39]. Lin et al. (2015) discusses how urban population agglomeration, industrial growth and investment drives land urbanization in different scales of cities in China [40]. There are evident regional differences for the expansion of construction land, and from 1989 to 2000 the expansion rate decreased slowly in China's east region but increased rapidly in China's west region. This difference arose because the construction land in the east was used intensively and the economic development did not cause an increase in per 
capita construction land in this region. Conversely, in the west, the construction land expanded very quickly at a two-dimensional (extensive) level, rather than at a three-dimensional (intensive) level, because of the relatively cheap land price, and because of the local policies to attract investment [41,42].

The second category of integrative studies explores the interactive coupling effect among the integrated values of economic development, CLU and ecological quality, by analyzing the nonlinear relationships. For example, Deng et al. (2010) analyze the relationship between economic growth and the urban core area with ordinary least squares and spatial statistical analysis [43]. Hui et al. (2015) reveal a positive coupling relationship between the urban scale and the land use intensity in 120 major Chinese cities in 2009, followed by the application of a structural equation model [44]. Cen et al. (2015) develop a coupling coordination to evaluate urban sustainability, and to discuss the interaction between the intensive land use and the landscape ecological security [45]. Nonomura et al. (2009) analyze the how extensive urban expansion and industrialization affect the atmospheric environment, using a 30-year data set to explore the impact of a low populated urban sprawl on the thermal environment [46]. Wang et al. (2014) apply an interactive coercing model to explore dynamic coordinated development of urban expansion and the change of environment in China [47]. Peng et al. (2016) establish an ECC (Ecological Carrying Capacity) model in the low-slope hilly regions to quantify potential of continuing population agglomeration, urbanization, and industrialization, in order to consider balance between mountain development and ecological protection[48].

The overall goal of this paper is to deepen understanding of the relationship changes in an integrated approach to the economy, CLU, and ecology in different stages of economic development in Zhejiang Province, China. Firstly, we apply a Granger causality test to explore the causality among economic growth, CLU and ecological quality, and an evaluation index system is proposed. Secondly, the study analyzes changes of the coupling coordinated development pattern and the constraints in different development stages based on a coupling coordination model.

\section{Materials and Methods}

\subsection{Study Area}

The study area, Zhejiang Province, lies in the southeast coastal region of China (Figure 5). Located in the Yangtze River Delta economic area, there is a $105,400 \mathrm{~km}^{2}$ of total land area with two sub-provincial cities, nine prefecture-level cities, and 90 counties in Zhejiang Province, roughly $70.4 \%$ of which is mountainous and hilly lands. Since the mid-1990s, Zhejiang has experienced a rapid industrialization and urbanization pace. Zhejiang's population increased by approximately 250\% between 1950 (22.8 million) and 2014 (55 million). In 2014, the total city population density reached 463.35 persons $/ \mathrm{km}^{2}$, considerably higher than the average overall population density (267.35 persons $/ \mathrm{km}^{2}$ ) of China at the time.

Zhejiang Province is one of the fastest economic growth regions in eastern China, and is renowned for its private enterprises. The private sector first came to prominence in China in the late 1970s, when the reform and opening up policy was firstly introduced. Today, one of every 25 people living in Zhejiang is a private business owner. Over the past 30 years, Zhejiang's traditional centrally planned economy has been completely transformed into a market-based economy. Many economic indicators (such as total product of the private economy, total sales value, total volume of retail sales, and total volume of foreign exchange-earnings) rank in first position in China for 10 consecutive years. In 2014, Zhejiang's GDP per capita was 73,312.81 yuan (approximately USD \$11,825), ranking it in fourth position out of the 34 provincial-level administrative units in China. The urban per capita disposable income was 40,393 yuan (approximately USD \$6515), and the average per capita government revenue reached a record of 13,667.9 yuan (approximately USD \$2205) [49].

However, the growth of economic activities and numbers of immigration of floating population have resulted in the continuous increase in the amount of construction land and the decline of cultivated land in the region and a corresponding decline in the grain yield. In the last three decades, with 
arbitrary occupation of highly productive cultivated land, Zhejiang's crop planting area decreased by $40 \%$, and its grain yield decreased by $47.93 \%$ [50,51]. Additionally, Zhejiang's industrialization drove the development of the townships and the village enterprises in the region. While such development improves rural employment, it also contributes to the pollution of the local environment, such as heavy metals in agricultural soils [52,53] and water pollution from leather industry [54]. The rapid expansion in the amount of construction land and the ongoing deterioration of the local environment are major concerns in Zhejiang Province.

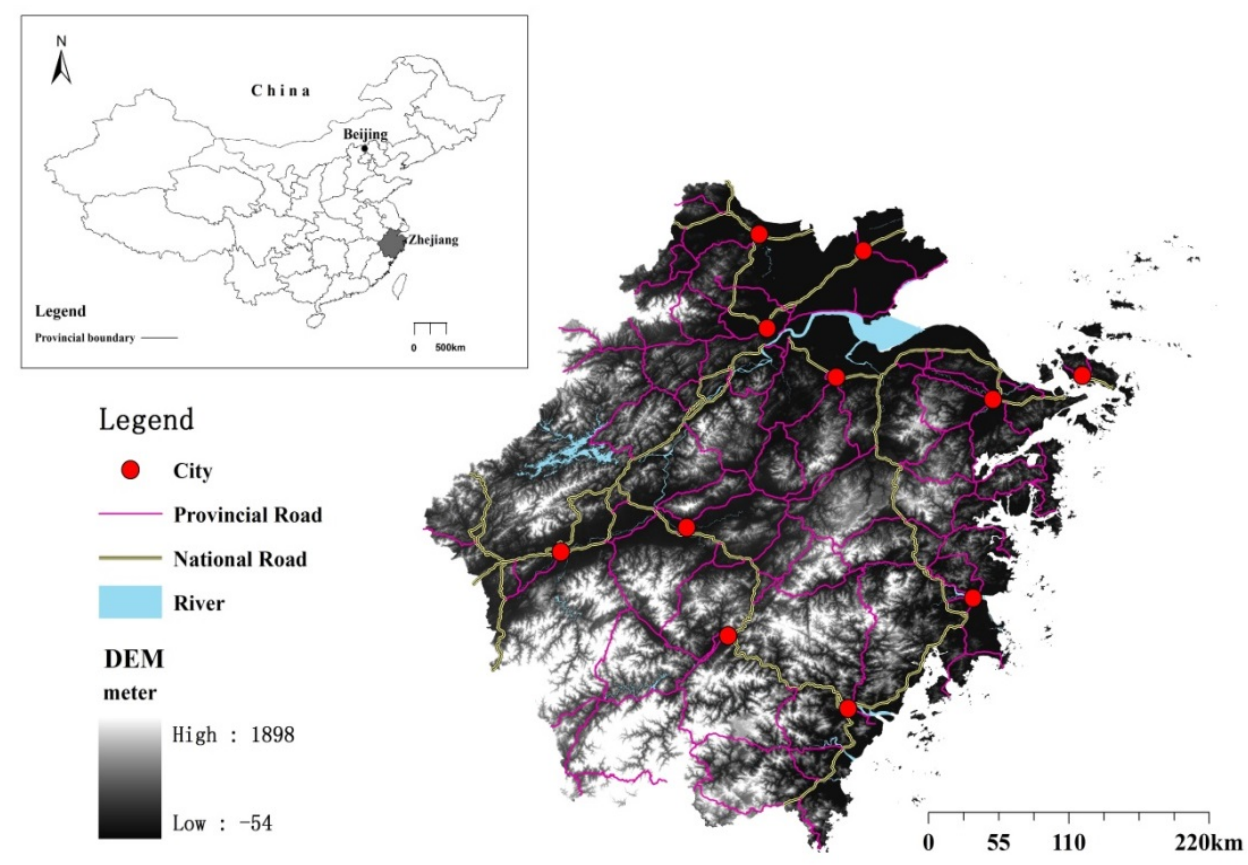

Figure 5. Location of the study area.

\subsection{Model Description and Methodology}

\subsubsection{Evaluation Index System}

Previous studies [45,47] followed three principles (the scientific, completeness, and feasible principles) to measure the coordinated development of an economic-CLU-ecology system. We define the economic-CLU-ecology system by evaluating its constituent indicators to produce a total integrated value for each subsystem (i.e., the economic, the CLU, and the ecology sub-systems). We use the integrated values for the economic-CLU-ecology system to assess the interrelationships among the subsystems and their impact on the overall system.

Economic subsystem: According to the characteristics of economic development, and its different stages of development in China, we established three indices (economic level, economic growth, and economic structure) to measure the integrated economic development value.

CLU subsystem: To promote the development mode to a more resource-saving manner, an input/output (I/0) index system from the view of investment, output and use density was established to measure the integrated value for CLU.

Ecology subsystem: We established a pressure-state-response (PSR) model to measure the integrated value for ecology. This PSR model reflects the causal relationships between the interactions of humans and the ecology (Table 1). 
Table 1. Measuring the integrated values for economic development, CLU and ecological quality.

\begin{tabular}{|c|c|c|c|c|}
\hline Objective Level & Indicator Level & - & - & - \\
\hline Composite Index & Single index & Weight & Correlation with Composite Index & Description \\
\hline \multirow{7}{*}{ Economic } & GDP per capita & 0.19 & Positive & Economic level \\
\hline & 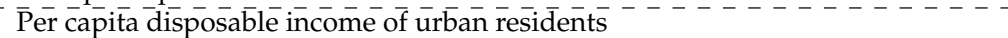 & $0.1 \overline{7}-$ & $\bar{P}^{-} \overline{s i t i v e}^{-}$ & \multirow{4}{*}{ Economic growth } \\
\hline & Rural per capita net income & 0.15 & Positive & \\
\hline & Growth rate of GDP & 0.16 & Positive & \\
\hline & $\overline{\text { Growth }} \overline{\text { rate of total revenue }} \overline{-}-\overline{-}$ & $0.1 \overline{0}$ & $\bar{P}^{-} \operatorname{sitive}^{-}$ & \\
\hline & Proportion of Tertiary Industry in GDP & 0.05 & Positive & \multirow{2}{*}{ Economic structure } \\
\hline & Urbanization rate & 0.18 & Positive & \\
\hline \multirow{7}{*}{$\begin{array}{l}\text { Construction land } \\
\text { use (CLU) }\end{array}$} & Fixed assets investment per unit construction land area & 0.18 & Positive & Land input level \\
\hline & 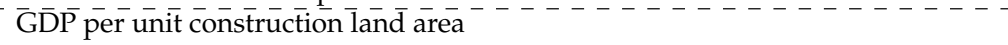 & $0.2 \overline{0}$ & $\bar{P}^{-}$ositive $^{-}$ & Land output benefit \\
\hline & Government revenue per unit conduction land area & 0.25 & Positive & Land output benefit \\
\hline & Construction land area per capita & $\overline{0.0 \overline{9}}$ & $\bar{N}$ egàtive- & \multirow{4}{*}{ Land use intensity } \\
\hline & Consumption of new construction land per unit of GDP growth & 0.09 & Negative & \\
\hline & Consumption of new construction land per unit of fixed assets investment & 0.11 & Negative & \\
\hline & Consumption of new construction land per unit of government revenue & 0.09 & Negative & \\
\hline \multirow{10}{*}{ Ecology } & Discharge of industrial waste water & 0.13 & Negative & \multirow{4}{*}{ Ecology pressure } \\
\hline & Emission of industrial $\mathrm{SO}_{2}$ & 0.09 & Negative & \\
\hline & Disposed industrial solid Waste & 0.15 & Negative & \\
\hline & Carbon emission intensity & 0.11 & Negative & \\
\hline & Cultivatè area per capita & $0.1 \overline{6}$ & Positive ${ }^{-}$ & \multirow{4}{*}{ Ecology level } \\
\hline & Greening ratio within constructed areas & 0.04 & Positive & \\
\hline & Green area per capita & 0.08 & Positive & \\
\hline & 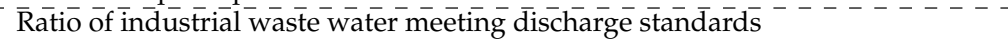 & $0.0 \overline{5}$ & Positive- & \\
\hline & Sewage Treatment Rate & 0.09 & Positive & \multirow[t]{2}{*}{ Ecology response } \\
\hline & Total investment in the treatment of Environmental pollution as percent of GDP & 0.09 & Positive & \\
\hline
\end{tabular}

life, of industrial development, and of transportation, respectively. The equation and parameter of Carbon emission intensity is from Sun and Liang [55]. 


\subsubsection{Data Sources and Processing}

The social and economic statistical data were obtained from the Zhejiang statistical yearbook and the construction land data were from the annual change survey data for land use in Zhejiang Province. The data processing can be seen in the flow diagram (Figure 6) and four major steps are included.

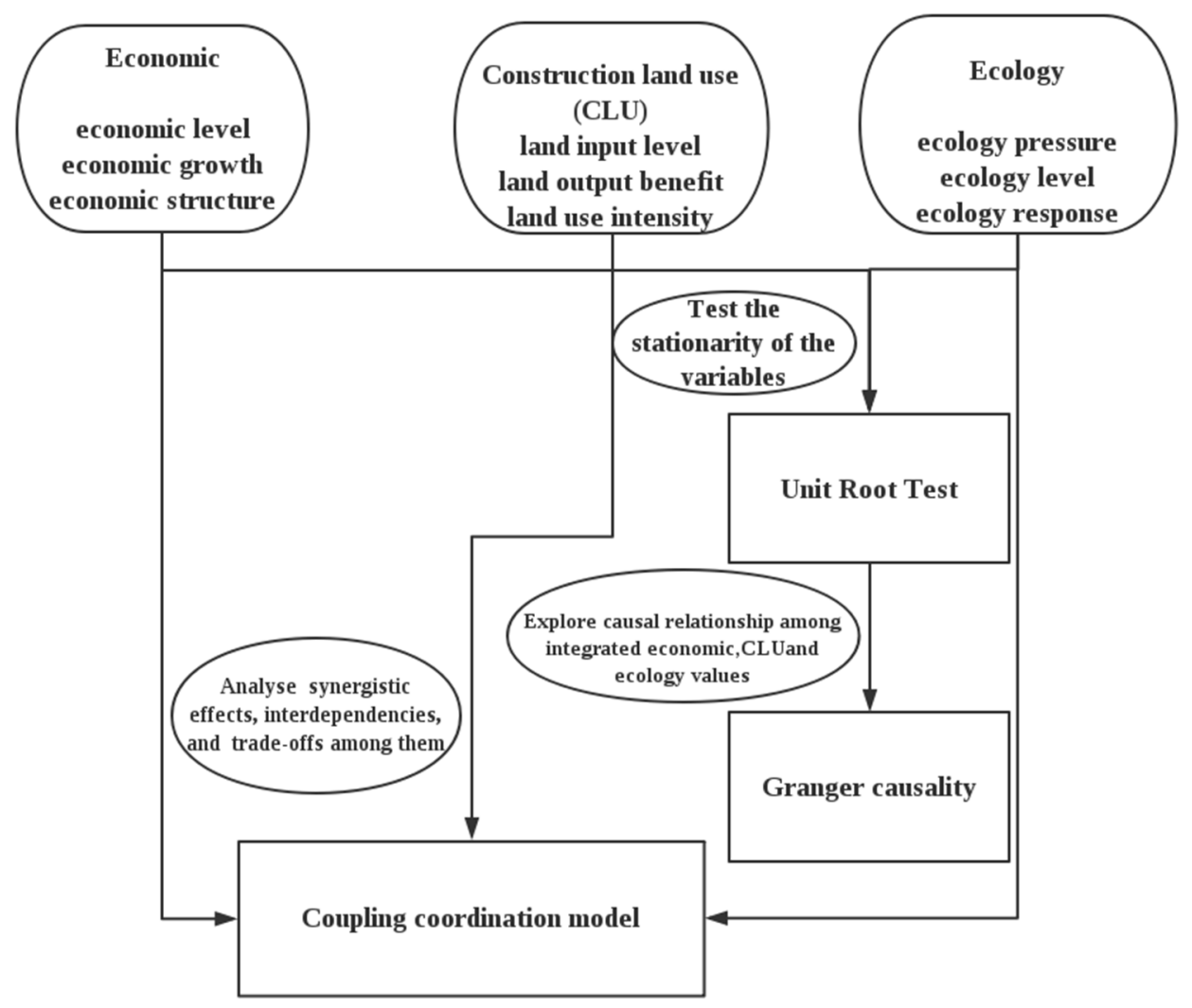

Figure 6. The flow diagram.

Firstly, we established an integrated system to evaluate the values of economic, CLU, and ecology from 2000 to 2012, and weights of indicators for subsystems were determined by an entropy method. The entropy method can express information and uncertainty [56], and is widely applied in landscape analysis [57], water management [58] and so on. We standardized the data to make them comparable, then calculated the integrated values throughout the time period by linear weighted method. The composites were calculated according to Equation (1):

$$
A_{i}=\sum_{j=1} U_{i j} \times \lambda_{j}
$$

where $A_{i}$ is the composite index, $\lambda_{j}$ represents the weight of the jth indicator, and $U_{i j}$ is the normalized value of each indicator.

Secondly, we examined the relationships among the integrated economic-CLU-ecology values. Generally, unit root test should be applied to test the stationarity of the variables. If the variables are determined to be stationary, we should test the cointegration relationship to examine whether there is a long-run relationship among them. In order to weaken heteroscedasticity effect, we conducted all the series tests after the logarithm fetch on the variables [59].

Thirdly, we used a Granger causality test to assess whether there was a long-term and stable equilibrium relationship between the three sub-systems. This enabled us to grasp the dynamic 
interaction process of the three subsystems. Note that when the Granger causality test is applied, all of the variables are in natural logarithms so that their first differences approximate their growth rates.

Finally, a coupling coordination model with coupling degree and coupling coordination degree was built to analyze the synergistic effects, the interdependencies, and the trade-offs among the integrated economic-CLU-ecology values from 2000 to 2012. The concept of coupling (where two or more systems interact), was first used in electronics physics, and was subsequently extended to many other disciplines. The measurement used for this influence is the coupling degree, which determines the way that the system goes when it reaches a critical value [60]. The socioeconomic system and the land use system were coupled by many researchers to analyze symbiotic or restrained factions in dynamic development. The coupling degree among the integrated values for economic-CLU-ecology can be calculated according to Equation (2):

$$
C=n \sqrt[n]{\frac{\prod_{k=1}^{n} U_{k}}{\left(\prod_{k=1}^{n} U_{K}\right)^{n}}}
$$

where $C$ is the coupling degree; and $U_{k}$ represents the integrated value for the economic, the CLU and the ecology subsystems, respectively.

Although the coupling degree of the integrated values for economic-CLU-ecology can be derived, it may raise status of pseudo highly coupling when all the subsystems are roughly equal but at a relatively lower level. Therefore, we calculated the coupling coordination degree in the following equations.

$$
\begin{aligned}
& D=\sqrt{C \times T} \\
& T=\sum_{\mathrm{k}=1}^{\mathrm{n}} \alpha_{\mathrm{k}} U_{\mathrm{k}}
\end{aligned}
$$

where $\mathrm{D}$ is coupling coordination degree, $\mathrm{C}$ is the coupling degree, and $\mathrm{T}$ reflects the overall effect on each other. For the $\mathrm{T}$ parameters that only had a limited impact on the coupling coordination degree $[12,61]$, the contribution value is set to be $1 / \mathrm{n}$.

\section{Results and Analysis}

\subsection{Integrated Values for the Economic, the CLU, and the Ecology Subsystems}

We compiled the integrated values for the three subsystems from their constituent indicators, shown in Table 1.

Figure 7 indicates that the integrated value for the ecology subsystem firstly declined, and then began to increase (with fluctuations) during 2000-2012, with appearances of points of inflexion in 2006, 2008 and 2010. The ecology pressure trend is similar to that of the integrated value for ecology, indicating that ecology pressure has a significant effect on the integrated value for ecology. The ecology subsystem trend for 2000-2006 was extremely similar with that of ecology pressure; from 2006-2010 it was consistent with ecology control; and during 2010-2012 it was consistent with ecology pressure and ecology control. There was a decrease of the values for ecology pressure and for ecology level in 2001, leading to a fall in the integrated value for ecology. This decrease was primarily caused by a sudden increase of built-up areas because of administrative regional adjustments. The integrated ecology value subsequently increased, as the ecology control values increased. However, the integrated ecology value was degraded under accumulated pressure. 


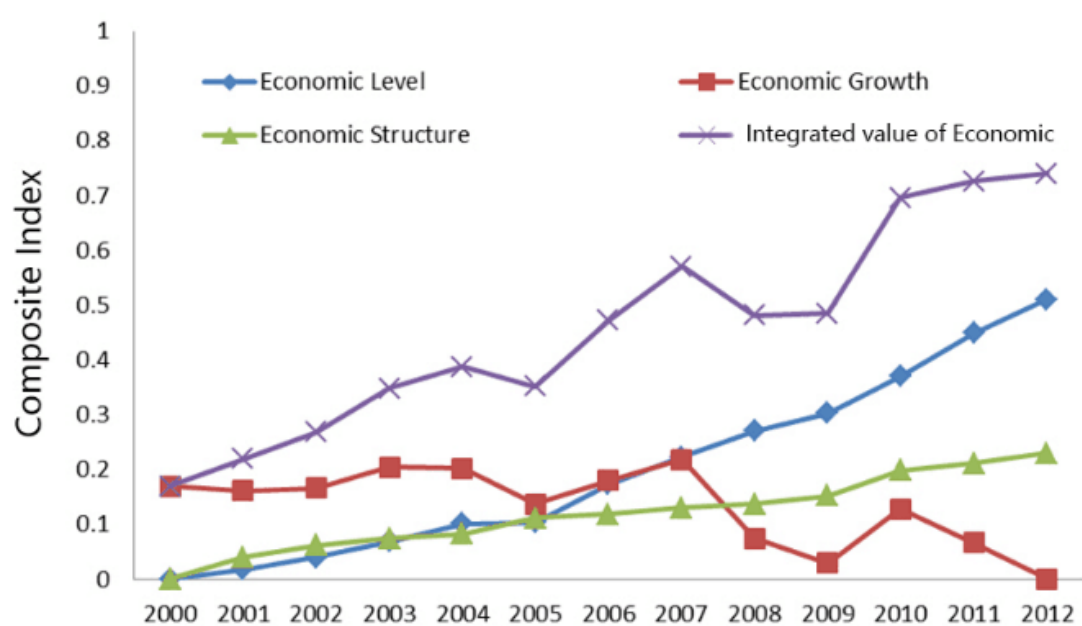

$2000 \quad 200120022003 \quad 2004 \quad 2005 \quad 2006 \quad 2007 \quad 2008 \quad 20092010 \quad 2011 \quad 2012$ Year

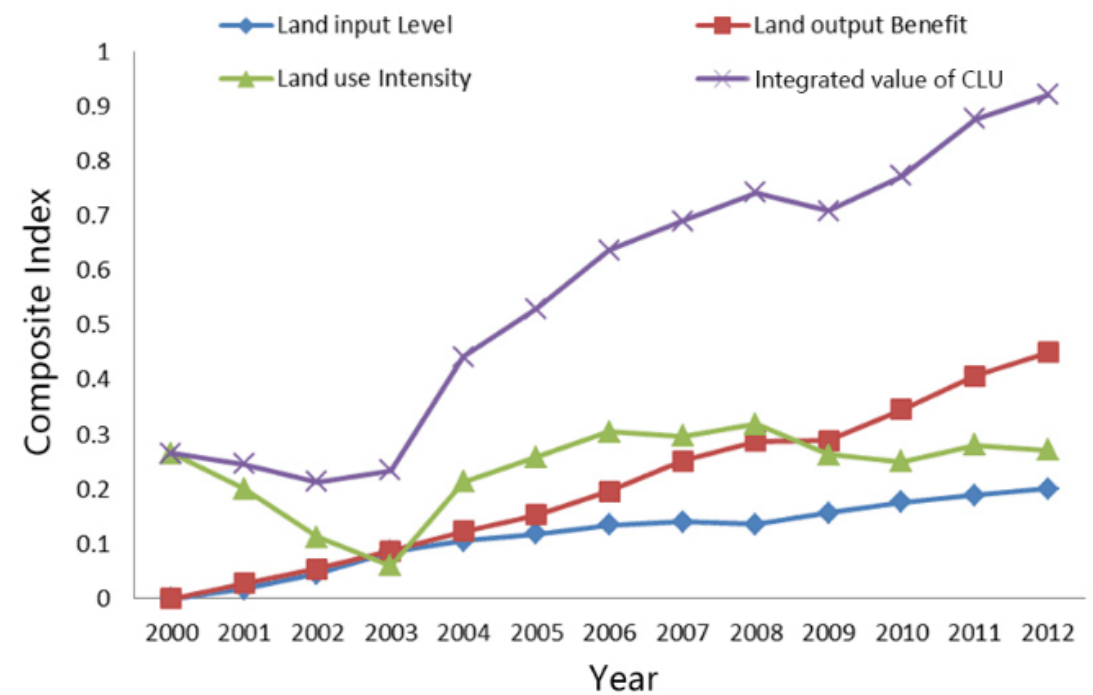

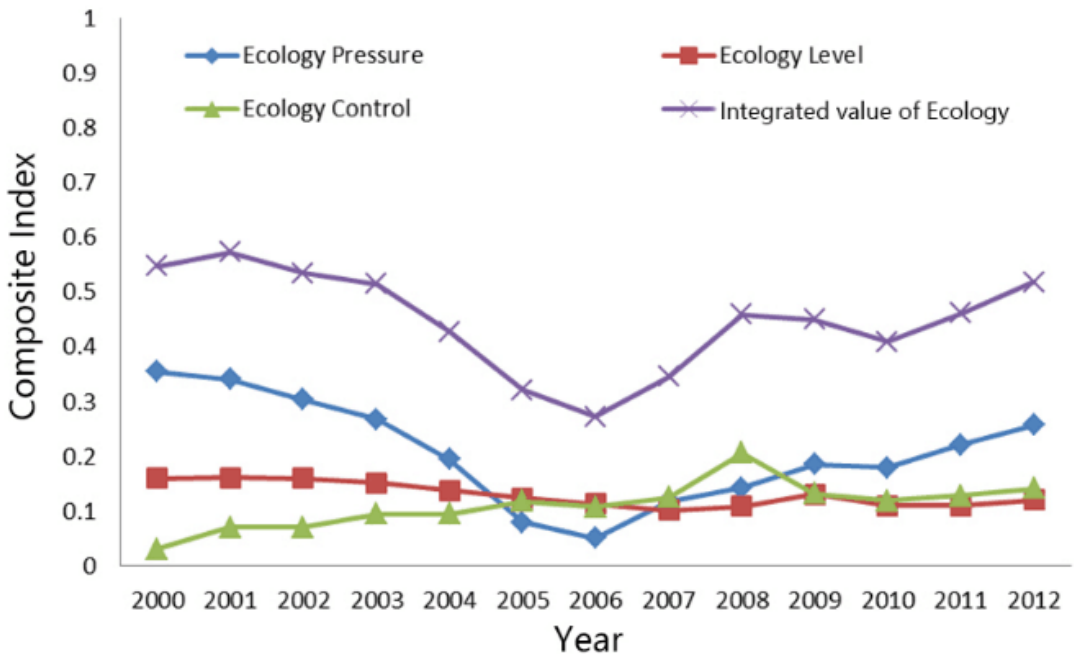

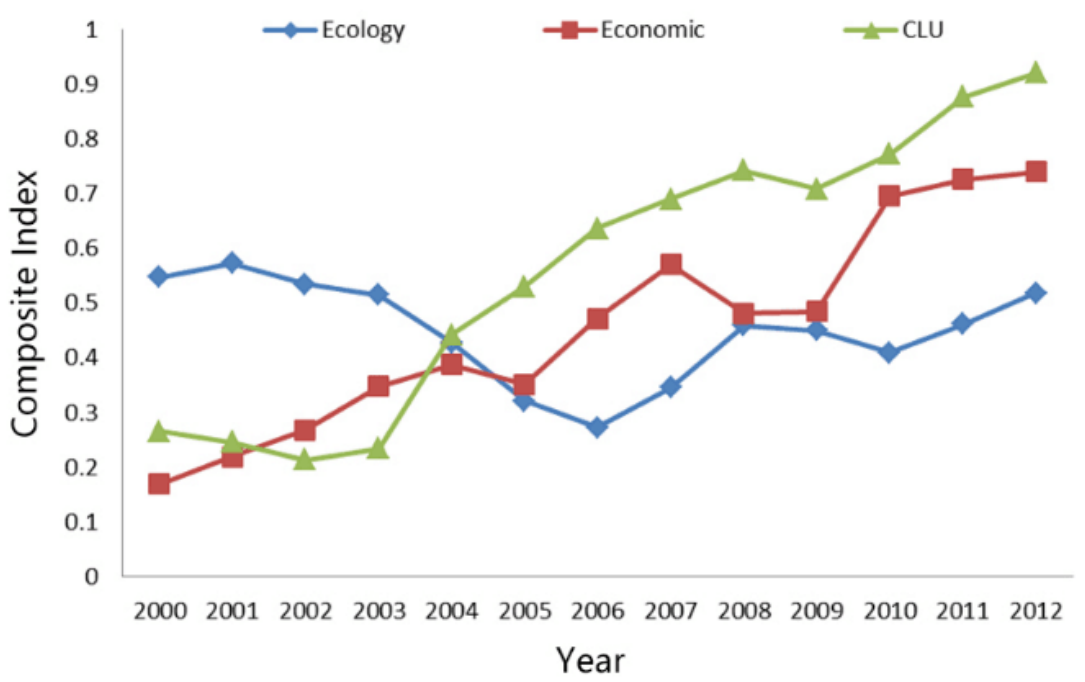

Figure 7. Integrated values for the economic, the CLU, and the ecology subsystems: Zhejiang Province, 2000-2012. 
The integrated value for the economic subsystem showed an increasing trend from 2000 to 2012, with two decreases in 2005 and 2008 (Figure 7). The integrated economic trend shows a similar trend to economic growth from 2000 to 2008, and a subsequent increase. The economic development level shows a consistent rapid increase, with economic structure also consistently improving, but at a slower rate. We conclude from this, that the current industrial adjustment needs further promotion.

The integrated value for the CLU subsystem increased consistently from 2000 to 2012, with a drop in 2009 (Figure 7). The integrated CLU trend showed a similar trend to that of land use intensity for 2000-2009, while after 2009 it was consistent with that of land input level and land output benefit. From 2003 to 2008, the values of all the constituent indicators increased, leading to an increase of the CLU integrated value. Since 2009, the CLU integrated value increased despite land use intensity decreasing, because the land input and the land output benefit values increased.

In 2000, the integrated ecology subsystem value was nearly twice that of the CLU subsystem, and roughly three times of that of the economic subsystem. Zhejiang Province was characterized by rapid urbanization and extensive economic development, along with deteriorating pollution and ecological pressure. The economy could be improved by a demographic increase; however, this would result in further ecological pollution, and in lagging urban infrastructure. Therefore, an increase in the non-agricultural population in the province aggravated the contradictions between humans and the land. China's new urbanization strategy and its ecology civilization construction since 2007 emphasize high technology and accessional value, high economic benefits, less resource consumption and less eco-environment pollution. These strategies reduced unfavorable influences of disordered urban expansion and extensive economic development on the ecology.

\subsection{Granger Sausality Test: Integrated Economic, CLU, and Ecology Subsystem Values}

Before conducting the Granger causality test on the integrated economic-CLU-ecology values, whether all the variables were stationary or not was necessary to test. We applied an ADF-Fisher test $[59,62]$ to unit root test. From Table 2, we concluded that all of the variables were not stationary at levels but were stationary at the first difference.

Table 2. Stationary test for the integrated economic, CLU, and ecology subsystem values.

\begin{tabular}{ccccccc}
\hline Variable & $\begin{array}{c}\text { ADF } \\
\text { Statistic }\end{array}$ & $\begin{array}{c}\text { Critical Value } \\
\text { at 1\% level }\end{array}$ & $\begin{array}{c}\text { Critical Value } \\
\text { at 5\% level }\end{array}$ & $\begin{array}{c}\text { Critical Value } \\
\text { at } \mathbf{1 0} \% \text { level }\end{array}$ & $\begin{array}{c}\text { Test Type } \\
\text { (C,T,L) }\end{array}$ & Test Result \\
\hline LnEcology & -2.68 & -4.40 & -3.18 & -2.73 & $(\mathrm{C}, 0,1)$ & unstable \\
LnEconomic & -3.44 & -5.30 & -4.00 & -3.46 & $(\mathrm{C}, \mathrm{T}, 2)$ & unstable \\
LnCLU & -1.63 & -4.99 & -3.88 & -3.38 & $(\mathrm{C}, \mathrm{T}, 0)$ & unstable \\
dLnEcology & -3.12 & -2.82 & -1.98 & -1.60 & $(0,0,1)$ & stable \\
dLnEconomic & -4.37 & -4.30 & -3.21 & -2.75 & $(\mathrm{C}, 0,1)$ & stable \\
dLnCLU & -1.98 & -2.79 & -1.98 & -1.60 & $(0,0,1)$ & stable \\
\hline
\end{tabular}

$\mathrm{C}, \mathrm{T}, \mathrm{L}$ means there exists constant term, time trend term and lag order, respectively; Ln means the natural logarithm; d means the first difference.

Because all of the variables were stationary at an order of one, 12 cointegration statistics contained in the Johansen cointegration test were used to estimate the long-run relationship among these variables. The trace test results clearly (Table 3 ) indicate three cointegration relationships at the 0.05 level.

Table 3. Results of unrestricted Cointegration Rank Test (Trace).

\begin{tabular}{ccccc}
\hline Hypothesized No. of CE(s) & Eigenvalue & Trace Statistic & 0.05 Critical Value & Prob.** $^{*}$ \\
\hline None $^{*}$ & 0.974876 & 73.92739 & 29.79707 & 0.0000 \\
At most 1 * & 0.946594 & 37.08823 & 15.49471 & 0.0000 \\
At most $2 *$ & 0.541132 & 7.789933 & 3.841466 & 0.0053 \\
\hline
\end{tabular}

* denotes rejection of the hypothesis at the 0.05 level; ** MacKinnon-Haug-Michelis (1999) $p$-values [63]. 
The Granger causality test results for the integrated economic-CLU-ecology values (Table 4) indicate there exists a one-way causal relationship between the integrated value in the economic and the ecology subsystems: the change of the integration value of Economic was the Granger cause of that of Ecology. There is a similar result in the Granger causality test for the economic and CLU subsystems, showing that the change of the integration value of Economic was the Granger cause of that of CLU.

Table 4. Pairwise Granger causality test for the economic, the CLU, and the ecology subsystems.

\begin{tabular}{|c|c|c|c|}
\hline Null Hypothesis & Observation & F-Statistic & Prob. \\
\hline dLnEconomic does not Granger Cause dLnEcology & & 70.17 & 0.01 * \\
\hline dLnEcology does not Granger Cause dLnEconomic & & 0.32 & 0.81 \\
\hline dLnEconomic does not Granger Cause dLnCLU & & 1120.10 & 0.00 * \\
\hline dLnCLU does not Granger Cause dLnEconomic & 9 & 0.88 & 0.57 \\
\hline dLnEcology does not Granger Cause dLnCLU & & 47.47 & $0.02 *$ \\
\hline dLnLnCLU does not Granger Cause dEcology & & 20.45 & 0.04 * \\
\hline
\end{tabular}

The lag order is determined by the vector auto-regression model; Ln means the natural logarithm; $\mathrm{d}$ means the first difference; ${ }^{*}$ denotes rejection of the hypothesis at the 0.05 level.

The results reveal that an extensive economic development in the initial stage of development would cause deteriorating pollution, non-agricultural population growth, and ecological pressure. Contrastingly, an intensive economic development mode (featuring low energy consumption, and an energy consumption structure adjustment) could reduce carbon emission intensity that could mitigate ecology pressure. With economic restructuring and an industrial structure adjustment, the construction land use structure could be optimized; hence improving the use and the allocation efficiency of the land resources. However, the improvement of the CLU integrated value did not significantly enhance economic development, which overwhelmingly depended on the increase of factor inputs.

Moreover, there is a two-way Granger causality relationship between the change of integrated values for ecology and CLU. This is because the physical and the economic intensities of CLU promoted the elements, and the condition of the ecosystem (particularly the carbon emission intensity), which led to ecology process changes.

Over $66 \%$ of the world's energy is consumed in urban areas, along with the production of over $70 \%$ of the global carbon dioxide $\left(\mathrm{CO}_{2}\right)$ emissions [64]. The optimization of industrial structures following energy restriction and energy conservation practices, urban planning and spatial optimization strategies are all shown to play an important role in the mitigation of $\mathrm{CO}_{2}$ emissions [65-67]. Accordingly, an urban land use with a compact development pattern would help to reduce $\mathrm{CO} 2$ emissions through improving urban eco-efficiency and resource efficiency, such as commuting eco-efficiency $[68,69]$. Additionally, the implementation of ecological conservation could regulate the land allocation and the configuration in the CLU, such as a basic farmland protection policy and new construction land control.

\subsection{Integrated Value for the Economic, the CLU, and the Ecology Subsystems: Coupling Results}

\subsubsection{Ecology-Economic Analysis}

The ecology and economic Coupling Coordination Degree (CD) initially increased, then decreased, and finally rose consistently, producing an S shaped curve for 2000-2012 (Figure 8). The ecology and economic $\mathrm{CD}$ increased by $44.4 \%$ over the 13 years, showing a growth in the balance between ecological and economic development. There was a clear decrease from 2003 to 2005, which could be concluded as the rapid economic development being beyond the capacity of the ecology. China joined the World Trade Organization in late 2001, and the extensive development model relating to this had a strong impact on resources, energy, and eco-environment. This imbalance likely occurred because China's local governments focused more on economic development than on the environmental carrying capacity. China launched a resource-saving and an environmentally friendly society construction 
strategy in 2006, at the start of its 11th five-year plan. This policy resulted in the $34.5 \%$ increase in the Ecology and Economic CD from 2006 to 2012.

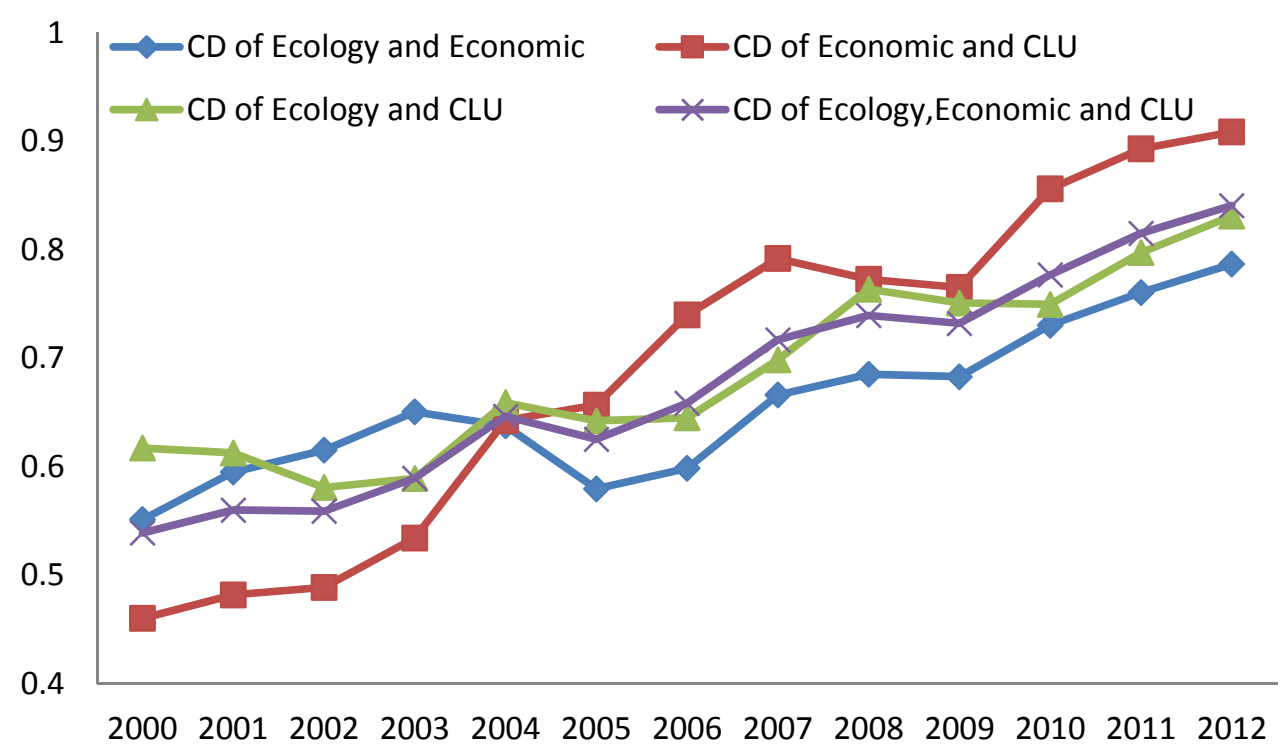

Figure 8. Coordination of the integrated economic-CLU-ecology values.

\subsubsection{Economic-CLU Analysis}

The Economic and CLU CD increased gradually from 0.46 to 0.81 from 2000 to 2012, with a slight fall (3.8\%) from 2007 to 2009 (Figure 8). This decrease implied that the global financial crisis had a serious impact on the land market, resulting in idle construction land. The local governments had a lack of funds, and lowered land prices to attract investment, which aggravated the inefficient industrial land use from 2000 to 2002. The urban expansion that started in 1998 had been misunderstood as constructing cities; this resulted in inefficient infrastructure use, and the huge waste of arable land resources. Therefore, there was a barely balanced economic and CLU development during 2000-2002. With urban development, the scarcity of the construction land resources improved the land input; this caused a turnaround to a better coordinated relationship between the economic and CLU subsystems. After 2010, another economic growth recession resulted in a slower increase in the economic and CLU CD.

\subsubsection{Ecology-CLU Analysis}

The ecology and CLU CD increased from 0.61 to 0.84 over the 13-year study period (Figure 8), which indicated that the coordination of the Ecology and the CLU subsystems was in a promotional process.

The trend of the ecology and CLU CD presents in three U-shaped curves from 2000-2012. The first U-shaped curve appeared from 2000 to 2004, with an inflection point in 2002. It should be pointed out that at a later stage of this period, the integrated CLU has begun to improve but that of ecology has kept declining. This indicates the integrated ecology subsystem is fragile and difficult to resume shortly. The second U-shaped curve occurred from 2004 to 2008, with an inflection point in 2006. In this period, the integrated CLU value gradually increased, while the integrated ecology value decreased, except for a rapid rise in 2008. This indicates once the ecological destruction was accumulated, it was difficult to recover to original state. Finally, the third U-shaped curve occurred from 2008 to 2012, with an inflection point in 2010.

In the initial period of urbanization, the CLU integration was less developed, and the Ecology integration was at a relatively high level. With urban expansion, human enjoyed benefits and 
facilitation by CLU, but the efficiency of CLU was restricted by technological level of social progress and people's consciousness. Similarly, the development of the ecology subsystem integration provided human value and wealth; however, the resilience, adaptability, and transformability of the socioeconomic-ecological systems restricted it.

\subsubsection{Economic-CLU-Ecology Analysis}

The economic-CLU-ecology CD increased roughly by 55.5\% from 2000 to 2012 (Figure 8), which indicated an increase in the balance among them. During the 2000-2004, the curve presents a similar trend to the economic-CLU CD curve, and thereafter is consistent with the ecology-economic CD curve. This indicates that coordination relationship of the economic aspect had the most overwhelming effect on the economic-CLU-ecology coordination because natural resources and human wealth were strongly affected by the rapid economic development.

\section{Discussion}

\subsection{Trade-offs among Economic Growth, CLU Development, and Ecology Protection}

Under the background of ecological civilization construction and new urbanization, with serious conflicts among land usages, ecological protection and economic growth, it is important to clear pivotal constraints of each period and identify priority sequences of economic, CLU, and ecology subsystems development.

Based on the Granger test, we find economic subsystem is the key for the sustainable development of modernization development and ecological protection because the change of integrated economic subsystem was the Granger cause of that of ecology and CLU values. However, in China pure economic growth itself may place much reliance on occupation of resources, such as energy consumption and arable land, but economic transition which plays an important role in promoting industrial structure, technical structure and productive ability can be a solution to the sustainable development.

The coupling model portrays the balance among economic, CLU, and ecology subsystems development. The change of constraint of the coupling relationship of integrated economic-CLUecology value indicates the main conflict of each modernization stage: The dependence on land finance of local government is the main reason of the low value of coupling relationship between integrated economic and CLU systems from 2000 to 2004. After 2004, the accumulative effect of the ecological overuse begins to arise so that in the future low carbon economic development which pays more attention to technological innovation and optimization of industrial structure with less high-emission energy consumption and less waste water and waste gas. Additionally, stakeholders can attempt to improve balance of modernization development and ecological protection through a price mechanism of construction land supply and eco-compensation method.

\subsection{Methodological Discussion}

The coordination among the sub-systems is the most important aspect of promoting to an ordered mechanism, which is more important than the balance of the current system and the distance of the system from balance state. This means that sustainable development is different from the expansion of the system. Therefore, an environmentally friendly method should be applied, to enhance human well-being and to guarantee the sustainable development of the economic-CLU-ecology system.

Evaluation models can be used to monitor and diagnose data for states or regions, and for the dynamics of socioeconomic and ecological systems. Such models provide a holistic view for combining a low-carbon economic development with ecological environments under rapid urbanization. There is only a coupling mode in our research area that provides trajectory of the evolution process, but we understand the change through economic theory and actual situation. The holistic view involves the conservation and the development of natural resources, the adjustment of the economic structure, and the optimization of the spatial patterns of land uses. 


\subsection{Limitations and Future Research Directions}

Aiming to promote harmony between humans and natures, the evaluation framework focus on the trade-off among resource utilization, human progress, and ecosystem protection, rather than pursues a certain subsystem's extreme of carrying capacity. However, due to complex relationships among various sub dimensions among the development of the economic-CLU-ecology system, there are still shortcomings in our study: (1) we ignore the interaction between indicators layers, so it is hard to clarify the causal relationships between these latent and observed variables in our study; (2) with subjectivity of evaluation itself, evaluation results have some uncertainty by weight setting of indices; and (3) the feature of temporal and spatial correlation is not analyzed in our study. In the future, we can explore more spatialized data to discuss their interconnection, and apply a structural equation model (SEM) approach which can provide coefficients for direct, indirect, and total effects of variables to identify and quantify the influence of factors.

\section{Conclusions}

Taking Zhejiang Province as an example, we proposed an updated comprehensive index system to assessing the socioeconomic and the eco-environment systems. The paper applied a Granger test, and developed a coupling coordination model to explore the synergistic effects, the interdependencies, and the trade-offs among the integrated economic-CLU-ecology values from 2000 to 2012.

We showed that the change of integrated economic subsystem was the Granger cause of changes to the integrated ecology and CLU values. We further showed that the integrated values for ecology and CLU were each other's Granger cause. This implied that the ecology and the CLU subsystems were sensitive to the change of industrialization and the economic structural, and several ecological issues and development conflicts had been raised from urbanization.

In the study period, looking at the sustainable development for the integrated economic-CLUecology values, the analysis of the coupling coordination model with the CD showed clear phases that can be divided into two short-term periods: from 2000 to 2004, and from 2004 to 2012. The coupling relationship between the integrated economic and CLU values had a constrained balanced development on the integrated economic-CLU-ecology value in the first period. The coupling relationship between the integrated ecology and economic values was the impediment for the sustainable development of economic-CLU-ecology in the second period.

The cultivated area per capita and the carbon emission intensity were found to have the greatest effects on the integrated value of the ecology subsystem. Further, the urbanization rate and the per capita disposable income of urban residents had the largest weights on the integrated value of the economic subsystem; and the GDP per unit construction land area and the government revenue per unit construction land area made the greatest contribution to the integrated value of the CLU subsystem. The results show the importance of building a low carbon and circular economic development mode, under the rapid population migration to urban and urban spatial sprawl conditions.

We argue that an intensive development pattern (rather than an extensive development pattern) would reduce the amount of resource consumption and improve productivity. This would solve the eco-environment problems under the back of economic development, which would achieve a sustainable development between the socioeconomic and the eco-environment systems.

Acknowledgments: We thank the following for their financial support for this project: the International S\&T Cooperation Program of China (2010DFA92720-27); the National Natural Science Foundation of China (Grants No. 30700098 and 40701007); Zhejiang Provincial Natural Science Foundation of China (Grants No. Y3090198 and Y507207); the key project of Zhejiang Provincial Education Department (Z201121260); and the Fundamental Research Funds for the Central Universities (2016XZZX004-02).

Author Contributions: Yan Li developed the original idea and contributed to the conceptual framework. Yan Li and Chuyu Xia wrote the paper and were responsible for data collection, process and analysis. Yanmei Ye and Zhou Shi provided guidance and improving suggestions. All authors have read and approved the final manuscript.

Conflicts of Interest: The authors declare no conflict of interest. 


\section{References}

1. Yin, K.; Wang, R.; An, Q.; Yao, L.; Liang, J. Using eco-efficiency as an indicator for sustainable urban development: A case study of Chinese provincial capital cities. Ecol. Indic. 2014, 36, 665-671. [CrossRef]

2. Koppenjan, J.F.M.; Enserink, B. Public-Private partnerships in urban infrastructures: reconciling private sector participation and sustainability. Public Adm. Rev. 2009, 69, 284-296. [CrossRef]

3. Ogu, V.I. Stakeholders' partnership approach to infrastructure provision and management in developing world cities: Lessons from the sustainable Ibadan project. Habitat Int. 2000, 24, 517-533. [CrossRef]

4. Liu, J.Y.; Kuang, W.H.; Zhang, Z.X.; Xu, X.L.; Qin, Y.W.; Ning, J.; Zhou, W.C.; Zhang, S.W.; Li, R.D.; Yan, C.Z.; et al. Spatiotemporal characteristics, patterns and causes of land use changes in China since the late 1980s. Acta Geograph. Sin. 2014, 69, 195-210. (In Chinese) [CrossRef]

5. Deng, X.; Gibson, J.; Wang, P. Management of trade-offs between cultivated land conversions and land productivity in Shandong Province. J. Clean. Prod. 2016. [CrossRef]

6. Deng, X.; Gibson, J.; Wang, P. Relationship between landscape diversity and crop production: A case study in the Hebei province of China based on multi-source data integration. J. Clean. Prod. 2016. [CrossRef]

7. Deng, X.; Huang, J.; Rozelle, S.; Zhang, J.; Li, Z. Impact of urbanization on cultivated land changes in China. Land Use Policy 2015, 45, 1-7. [CrossRef]

8. Bao, C.; Fang, C.-1. Water resources constraint force on urbanization in water deficient regions: A case study of the Hexi Corridor, arid area of NW China. Ecol. Econ. 2007, 62, 508-517. [CrossRef]

9. Jaeger, J.A.G.; Bertiller, R.; Schwick, C.; Kienast, F. Suitability criteria for measures of urban sprawl. Ecol. Indic. 2010, 10, 397-406. [CrossRef]

10. Fang, C.L.; Guan, X.L.; Lu, S.S.; Zhou, M.; Deng, Y. Input-Output efficiency of urban agglomerations in China: An application of data envelopment analysis (DEA). Urban Stud. 2013. [CrossRef]

11. Yin, J. Study on the Growth of Construction Land and Its Management: Lessons from Japan. Master's Thesis, Zhejiang University, Hangzhou, China, 2010. (In Chinese)

12. Li, Y.F.; Li, Y.; Zhou, Y.; Shi, Y.; Zhu, X. Investigation of a coupling model of coordination between urbanization and the environment. J. Environ. Manag. 2012, 98, 127-133. [CrossRef] [PubMed]

13. Yang, X.; Yue, W.; Xu, H.; Wu, J.; He, Y. Environmental consequences of rapid urbanization in Zhejiang province, east China. Int. J. Environ. Res. Public Health 2014, 11, 7045-7059. [CrossRef] [PubMed]

14. Mu, Y.; Qian, Z.H. Study on the path selection of cracking local government's land fiscal dilemma. China Land Sci. 2015, 29, 19-25.

15. Ding, C. Land policy reform in China: Assessment and prospects. Land Use Policy 2003, 20, 109-120. [CrossRef]

16. Li, X. Research on the Allocation of Construction Land Increment on the Loss of Farmland Resources Perspective-An Empirical Study on China in Transition. Ph.D. Thesis, Nanjing Agricultural University, Nanjing, China, 2010. (In Chinese)

17. Chen, H.; Jia, B.; Lau, S.S.Y. Sustainable urban form for Chinese compact cities: Challenges of a rapid urbanized economy. Habitat Int. 2008, 32, 28-40. [CrossRef]

18. Zhang, T. Land market forces and government's role in sprawl: The case of China. Cities 2000, 17, 123-135. [CrossRef]

19. Long, H.; Li, Y.; Liu, Y.; Woods, M.; Zou, J. Accelerated restructuring in rural China fueled by 'increasing vs. decreasing balance' land-use policy for dealing with hollowed villages. Land Use Policy 2012, 29, 11-22. [CrossRef]

20. Shen, J. A study of the temporary population in Chinese cities. Habitat Int. 2002, 26, 363-377. [CrossRef]

21. Wang, J.; Chen, Y.; Shao, X.; Zhang, Y.; Cao, Y. Land-use changes and policy dimension driving forces in China: Present, trend and future. Land Use Policy 2012, 29, 737-749. [CrossRef]

22. Jiang, D.; Li, X.; Qu, F.; Li, M.; Zhang, S.; Gong, Y.; Shi, X.; Chen, X. Driving mechanism and boundary control of urban sprawl. Front. Environ. Sci. Eng. 2015, 9, 298-309. [CrossRef]

23. Wu, Y.; Zhang, X.; Skitmore, M.; Song, Y.; Hui, E.C.M. Industrial land price and its impact on urban growth: A Chinese case study. Land Use Policy 2014, 36, 199-209. [CrossRef]

24. Xin, J. Research on the Mechanism and Method of Evaluation of Land Output Efficiency of Industrial Park. Ph.D. Thesis, Fudan University, Shanghai, China, 2012. (In Chinese) 
25. Fei, J. Study on the Driving Force and Restraint Mechanism of Regional Industrial Land Expanison: Based on an Integrated Framework of Industry Development and Land Policy. Master's Thesis, Zhejiang University, Hangzhou, China, 2012. (In Chinese)

26. Geurs, K.T. Job accessibility impacts of intensive and multiple land-use scenarios for the Netherlands' Randstad Area. J. Hous. Built Environ. 2006, 21, 51-67. [CrossRef]

27. Kong, W.; Guo, J.; Ou, M. Study on land intensive use response on economic development and regional differentiated control of constructed land. China Popul. Resour. Environ. 2014, 24, 100-106. (In Chinese)

28. McDonald, J.F. Capital-Land substitution in urban housing: A survey of empirical estimates. J. Urban Econ. 1981, 9, 190-211. [CrossRef]

29. Pasche, M. Technical progress, structural change, and the environmental Kuznets curve. Ecol. Econ. 2002, 42, 381-389. [CrossRef]

30. Liu, Y.; Li, R.; Song, X. Grey associative analysis of regional urbanization and eco-environment coupling in China. Acta Geogr. Sin. 2005, 60, 237-247. (In Chinese)

31. Huang, J.; Fang, C. Analysis of coupling mechanism and rules between urbanization and eco-environment. Geogr. Res. 2003, 22, 211-220.

32. Dinda, S. Environmental Kuznets curve hypothesis: A survey. Ecol. Econ. 2004, 49, 431-455. [CrossRef]

33. Nahman, A.; Antrobus, G. The environmental Kuznets curve: A literature survey. S. Afr. J. Econ. 2005, 73, 105-120. [CrossRef]

34. Kijima, M.; Nishide, K.; Ohyama, A. Economic models for the environmental Kuznets curve: A survey. J. Econ. Dyn. Contr. 2010, 34, 1187-1201. [CrossRef]

35. Jurdi, M.; Korfali, S.I.; Karahagopian, Y.; Davies, B.E. A prototype study for the management of surface water resources, Lebanon. Water Policy 2001, 3, 41-46. [CrossRef]

36. Fang, C.; Wang, J. A theoretical analysis of interactive coercing effects between urbanization and eco-environment. Chin. Geogr. Sci. 2013, 23, 147-162. [CrossRef]

37. Chen, M.; Lu, D.; Zhang, H. Comprehensive evaluation and the driving factors of China's urbanization. Acta Geogr. Sin. 2009, 64, 387-398.

38. Shu, B.; Zhu, J.; Li, Y.; Qu, Y.; Yong, X. Driving forces of urban land expansion at different stages of economic development: An empirical analysis based on provincial panel data. China Land Sci. 2013, 27, 65-71. (In Chinese)

39. Ye, H.; Zhang, P.; Pu, L. Spatial econometrics study of relationship between regional socio-economic development and construction land in China. Sci. Geograph. Sin. 2012, 2, 149-155.

40. Lin, X.; Yang, W.; Wang, S.; Wang, D. Spatial differences and driving forces of land urbanization in China. J. Geograph. Sci. 2015, 25, 545-558. [CrossRef]

41. Xie, H.; Liu, Z.; Wang, P.; Liu, G.; Lu, F. Exploring the mechanisms of ecological land change based on the spatial autoregressive model: a case study of the Poyang lake eco-economic zone, China. Int. J. Environ. Res. Public Health 2014, 11, 583-599. [CrossRef] [PubMed]

42. Xie, H.; Wang, P.; Huang, H. Ecological risk assessment of land use change in the Poyang lake eco-economic zone, China. Int. J. Environ. Res. Public Health 2013, 10, 328-346. [CrossRef] [PubMed]

43. Deng, X.; Huang, J.; Rozelle, S.; Uchida, E. Economic growth and the expansion of urban land in China. Urban Stud. 2010, 47, 813-843. [CrossRef]

44. Hui, E.C.M.; Wu, Y.; Deng, L.; Zheng, B. Analysis on coupling relationship of urban scale and intensive use of land in China. Cities 2015, 42, 63-69. [CrossRef]

45. Cen, X.; Wu, C.; Xing, X.; Fang, M.; Garang, Z.; Wu, Y. Coupling intensive land use and landscape ecological Security for urban sustainability: An integrated socioeconomic data and spatial metrics analysis in Hangzhou city. Sustainability 2015, 7, 1459-1482. [CrossRef]

46. Nonomura, A.; Kitahara, M.; Masuda, T. Impact of land use and land cover changes on the ambient temperature in a middle scale city, Takamatsu, in southwest Japan. J. Environ. Manag. 2009, 90, 3297-3304. [CrossRef] [PubMed]

47. Wang, S.; Ma, H.; Zhao, Y. Exploring the relationship between urbanization and the eco-environment-A case study of Beijing-Tianjin-Hebei region. Ecol. Indicat. 2014, 45, 171-183. [CrossRef]

48. Peng, J.; Du, Y.; Liu, Y.; Hu, X. How to assess urban development potential in mountain areas? An approach of ecological carrying capacity in the view of coupled human and natural systems. Ecol. Indicat. 2016, 60, 1017-1030. [CrossRef] 
49. Zhejiang Statistical Bureau. Zhejiang Statistical Yearbook 2014; Chinese Statistical Publishing House: Beijing, China, 2014; pp. 2-9.

50. Li, Y.; Wu, H.; Shi, Z. Farmland productivity and its application in spatial zoning of agricultural production: a case study in Zhejiang province, China. Environ. Earth Sci. 2016, 75, 1-17. [CrossRef]

51. Li, Y.; Shi, Z.; Wu, H.X.; Li, F.; Li, H.Y. Definition of management zones for enhancing cultivated land conservation using combined spatial data. Environ. Manag. 2013, 52, 792-806. [CrossRef] [PubMed]

52. Cheng, J.; Shi, Z.; Zhu, Y. Assessment and mapping of environmental quality in agricultural soils of Zhejiang province, China. J. Environ. Sci. 2007, 19, 50-54. [CrossRef]

53. Naveedullah; Hashmi, M.Z.; Yu, C.; Shen, H.; Duan, D.; Shen, C.; Lou, L.; Chen, Y. Risk assessment of heavy metals pollution in agricultural soils of siling reservoir watershed in Zhejiang province, China. BioMed Res. Int. 2013. [CrossRef] [PubMed]

54. Zhang, M.Q.; Zhang, M.H. Assessing the impact of leather industry to water quality in the Aojing watershed in Zhejiang province, China. Environ. Monit. Assess. 2006, 115, 321-333. [CrossRef] [PubMed]

55. Sun, H.; Liang, H.; Chang, X.; Cui, Q.; Tao, Y. Land use patterns on carbon emission and spatial association in China. Econ. Geogr. 2015. [CrossRef]

56. Shannon, C.E. A mathematical theory of communication. ACM SIGMOBILE Mob. Comput. Commun. Rev. 2001, 5, 3-55. [CrossRef]

57. Antrop, M. Landscape change: Plan or chaos? Landsc. Urban Plann. 1998, 41, 155-161. [CrossRef]

58. Zou, Z.; Yun, Y.; Sun, J. Entropy method for determination of weight of evaluating indicators in fuzzy synthetic evaluation for water quality assessment. J. Environ. Sci. 2006, 18, 1020-1023. [CrossRef]

59. Ou, J.; Liu, X.; Li, X.; Chen, Y. Quantifying the relationship between urban forms and carbon emissions using panel data analysis. Landsc. Ecol. 2013, 28, 1889-1907. [CrossRef]

60. Liu, Y.; Xu, J.; Luo, H. An integrated approach to modelling the economy-society-ecology system in urbanization process. Sustainability 2014, 6, 1946-1972. [CrossRef]

61. Yuan, Y.; Jin, M.; Ren, J.; Hu, M.; Ren, P. The dynamic coordinated development of a regional environment-tourism-economy system: A case study from western Hunan province, China. Sustainability 2014, 6, 5231-5251. [CrossRef]

62. Al-mulali, U.; Fereidouni, H.G.; Lee, J.Y.M.; Sab, C.N.B.C. Exploring the relationship between urbanization, energy consumption, and $\mathrm{CO}_{2}$ emission in MENA countries. Renew. Sustain. Energ. Rev. 2013, 23, 107-112. [CrossRef]

63. Mackinnon, J.G.; Haug, A.A.; Michelis, L. Numerical distribution functions of likelihood ratio tests for cointegration. J. Appl. Econ. 1999, 14, 563-577. [CrossRef]

64. Wang, S.; Fang, C.; Wang, Y.; Huang, Y.; Ma, H. Quantifying the relationship between urban development intensity and carbon dioxide emissions using a panel data analysis. Ecol. Indic. 2015, 49, 121-131. [CrossRef]

65. Imhoff, M.L.; Zhang, P.; Wolfe, R.E.; Bounoua, L. Remote sensing of the urban heat island effect across biomes in the continental USA. Rem. Sens. Environ. 2010, 114, 504-513. [CrossRef]

66. Liu, M.; Tao, Y.; Li, D.; Xia, B.; Wang, Y. Exploring on urban land development intensity based on artificial neural network methods. J. Comput. 2013, 8, 3119-3125. [CrossRef]

67. Zhou, D.; Zhao, S.; Liu, S.; Zhang, L. Spatiotemporal trends of terrestrial vegetation activity along the urban development intensity gradient in China's 32 major cities. Sci. Total Environ. 2014, 488-489, 136-145. [CrossRef] [PubMed]

68. Wang, Y.; Hayashi, Y.; Chen, J.; Li, Q. Changing urban form and transport CO2 emissions: an empirical analysis of Beijing, China. Sustainability 2014, 6, 4558-4579. [CrossRef]

69. Liu, Y.; Song, Y.; Arp, H.P. Examination of the relationship between urban form and urban eco-efficiency in China. Habitat Int. 2012, 36, 171-177. [CrossRef]

(C) 2016 by the authors; licensee MDPI, Basel, Switzerland. This article is an open access article distributed under the terms and conditions of the Creative Commons Attribution (CC-BY) license (http:/ / creativecommons.org/licenses/by/4.0/). 